\title{
GFAP Promoter Directs Astrocyte-specific Expression in Transgenic Mice
}

\author{
Michael Brenner, ${ }^{1}$ William C. Kisseberth, ${ }^{2}$ Yuan Su, ${ }^{1}$ Francois Besnard, ${ }^{1}$ and Albee Messing ${ }^{2}$ \\ 'Laboratory of Molecular Biology, National Institute of Neurological Disorders and Stroke, National Institutes of Health, \\ Bethesda, Maryland 20892 and ${ }^{2}$ Department of Pathobiological Sciences, School of Veterinary Medicine, University of \\ Wisconsin-Madison, Madison, Wisconsin 53706
}

\begin{abstract}
Glial fibrillary acidic protein (GFAP) is an intermediate-filament protein expressed abundantly and almost exclusively in astrocytes of the CNS. We are studying transcriptional regulation of the GFAP gene to gain insight into astrocyte function and also to develop an astrocyte-specific expression system for manipulating brain physiology. In this work, we have produced transgenic mice carrying the bacterial lac $Z$ reporter gene linked to a 2.2 kilobase 5 '-flanking sequence derived from the human GFAP gene that previously was shown to direct astrocyte-specific transcription in cultured cells. We report that this promoter directs expression to astrocytes in the CNS. In addition, the upregulation of GFAP gene activity that follows injury to the brain was mimicked by the transgene. One of the transgenes was found to be $X$-linked and appeared to undergo the usual random inactivation that achieves gene dosage compensation in females. The brains of hemizygous females stained uniformly rather than displaying mosaic patches, indicating that astrocytes intermingle following their formation. The specific expression of the GFAP-lacZ transgene means that it is now possible to target expression of other heterologous genes to astrocytes in vivo, and to study the mechanisms for reactive gliosis at the DNA level.
\end{abstract}

[Key words: astrocyte, glial fibrillary acidic protein, transgenic, gliosis, transcription, mouse]

Astrocytes comprise one of the major cell populations of the vertebrate CNS, where they carry out a wide-ranging set of activities (Fedoroff and Vernadakis, 1986a,b; Norenberg et al., 1988). Expression of glial fibrillary acidic protein (GFAP), an intermediate-filament protein, is one of the hallmarks of astrocytic differentiation during development (Dahl, 1981; Bovolenta et al., 1984), and of the reactive gliosis that follows a myriad of injuries to the CNS (Bignami and Dahl, 1976; Mathewson and Berry, 1985). Although many factors have been shown to regulate expression of GFAP in cultured astrocytes (Goldman

\footnotetext{
Received Apr. 14, 1993; revised July 27, 1993; accepted Aug. 9, 1993.

We thank Dr. Ian D. Duncan for reviewing the electron micrographs of the optic nerve, Ms. Denice Springman for technical assistance, Drs. Richard Behringer and Lynn Hudson for comments on the manuscript, and Devera Schoenberg, M.S., for manuscript preparation. Work at the University of Wisconsin was supported by Grant RG 2487-A-1 of the National Multiple Sclerosis Society to A.M., who is a Shaw Scholar of the Milwaukee Foundation. This article is dedicated to Dr. Ernst Freese, the late Chief of the Laboratory of Molecular Biology, NINDS, whose vision engendered this project.

Correspondence should be addressed to Michael Brenner, Building 36, Room 4D-04, SB/NINDS/NIH, Bethesda, MD 20892.

Copyright (C) 1994 Society for Neuroscience $0270-6474 / 94 / 141030-08 \$ 05.00 / 0$
}

and Chiu, 1984; Morrison et al., 1985; Shafit-Zagardo et al., 1988; O'Callaghan et al., 1991), the molecular mechanisms of regulation in vivo are unknown (Eng, 1988).

Genomic clones have been isolated for the mouse and human GFAP genes (Balcarek and Cowan, 1985; Brenner et al., 1990), and have been analyzed to identify regions required for transcriptional activity (Miura et al., 1990; Nakatani et al., 1990; Besnard et al., 1991; Sarid, 1991; Sarkar and Cowan, 1991; Masood et al., 1993). In particular, a promoter ( $g f a 2)$ consisting of 2.2 kilobase $(\mathrm{kb})$ of $5^{\prime}$-flanking DNA of the human GFAP (hGFAP) gene has been found to drive astrocyte-specific expression in cultured cells (Besnard et al., 1991). With the twin goals of extending this regulatory analysis to the more stringent system of an intact animal, and of developing an astrocytespecific expression system for manipulating CNS physiology, we joined the $g / a 2$ promoter to an Escherichia coli $\beta$-galactosidase reporter gene (lac $Z$ ) and studied its expression in transgenic mice.

\section{Materials and Methods}

Transgenic mouse production. The cytoplasmic and nuclear-targeted gfa2-lacZ transgenes were constructed by inserting the $2.2 \mathrm{~kb} \mathrm{KpnI-}$ SalI fragment of pGfaCAT-2 (Besnard et al., 1991) between the KpnI and SalI sites of placF and pnlacF, respectively (gift of $R$. D. Palmiter, University of Washington, Seattle, WA) (Mercer et al., 1991). The transgenes were excised with Bglll, purified by agarose gel electrophoresis, and recovered by adsorption onto glass (GeneClean, Bio 101, La Jolla, CA). Transgenic mice were produced according to standard techniques by microinjecting $2 \mathrm{pl}$ of a solution of DNA into the male pronucleus of fertilized eggs obtained from the mating of either inbred FVB/N mice for the cytoplasmic gfa2-lacZ, or F1 hybrid C57BL/6J $\times$ SJL mice (Brinster et al., 1985) for the nuclear gfa2-lacZ. Three of the lines described in this report have been assigned designations according to the standardized rules for genetic nomenclature in transgenic mice: line 6-4, Tg(GFAP, lacZ)Mes1; line 7-1, Tg(GFAP,lacZ)Mes2; line7-2, $\mathrm{Tg}(\mathrm{X} ; \mathrm{GFAP}, \operatorname{lacZ}) \mathrm{Mes} 3$.

lacZ histochemistry. Ex pression of the bacterial lac $Z$ gene was detected by standard histochemical reactions (Mercer et al., 1991). For staining of brain slices or fetuses, the tissues were immersion fixed in ice-cold $2 \%$ formalin, $0.2 \%$ glutaraldehyde in $0.1 \mathrm{~m}$ sodium phosphate buffer,

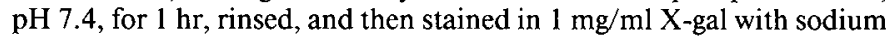
deoxycholate and NP-40 to enhance permeability. Staining was routinely performed at $37^{\circ} \mathrm{C}$ in the dark for $12-18 \mathrm{hr}$.

Double labeling of vibratome sections. For vibratome sections, brains of mice perfused with $4 \%$ paraformaldehyde in $0.1 \mathrm{M}$ sodium phosphate buffer, $\mathrm{pH} 7.4$, were postfixed an additional hour on ice. Vibratome sections $(50-100 \mu \mathrm{m})$ were first stained by X-gal histochemistry, and then immunostained for GFAP according to standard procedures using the avidin-biotin-peroxidase method (Vector Laboratories, Burlingame, CA). The primary GFAP antibody, a polyclonal rabbit antibovine GFAP antibody (Dako, Carpinteria, CA), was used at a 1:500 dilution. Sections were then mounted in $80 \%$ glycerol/PBS with $5 \%$ 


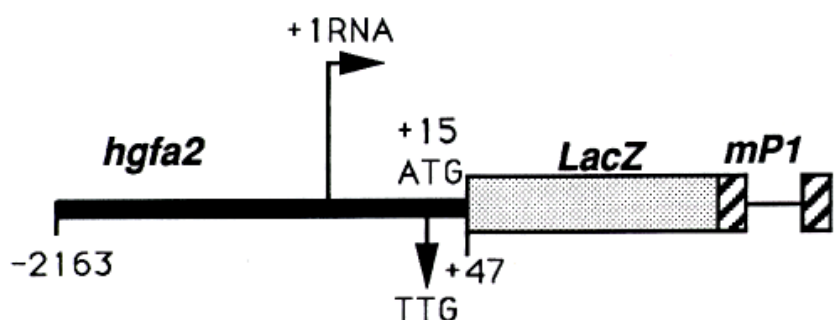

Figure 1. gfa2-lac $Z$ transgene. The hGFAP fragment spans bp -2163 to +47 relative to the transcriptional start site and has the natural initiating ATG at bp +15 converted to TTG by site-directed mutagenesis so that protein synthesis initiates within lacZ. Also present are the coding region for $\beta$-galactosidase (lacZ), and a segment of the mouse protamine-1 gene $(m P 1)$ that provides an intron (thin line) and a polyadenylation site.

$N$-propyl gallate. Controls included omission of the primary antibody for the immunocytochemistry, and nontransgenic littermates for the $\mathrm{X}$-gal histochemistry.

lacZ solution assay. lac $Z$ enzymatic activity was assayed in extracts of tissues by detection of conversion of 4-methylumbelliferyl-D-galactoside (MUG) into a fluorescent product, as described in the technical manual for the Hoefer (San Francisco, CA) TKO-100 minifluorometer. Briefly, tissue was homogenized in a reaction buffer consisting of 25 mм Tris- $\mathrm{HCl}$, pH 7.5, $125 \mathrm{~mm} \mathrm{NaCl}, 2 \mathrm{~mm} \mathrm{MgCl}_{2}$, and $12 \mathrm{~mm}$ 2 -mercaptoethanol. Homogenates were spun in a microfuge, and aliquots or dilutions of the supernatant were incubated with $0.25 \mathrm{~mm}$ MUG for $30 \mathrm{~min}$ at $37^{\circ} \mathrm{C}$. The reaction was stopped by addition of trichloroacetic acid to $5 \%$ and the fluorescence was read from an aliquot of the reaction mixture diluted in a glycine-carbonate buffer, $\mathrm{pH} 10.7$. Spiking samples of various tissues from control mice with purified enzyme prior to assay showed that there were no inhibitors present. Protein content of each sample was measured with the Bradford assay (BioRad, Richmond, CA), and enzymatic activity expressed as thousands of fluorescence units per milligram of protein.

Electron microscopic analysis of lacZ-expressing cells. For electron microscopic visualization of the lac $Z$ reaction product, tissues were stained with Bluo-gal according to standard methods (Vandaele et al., 1991; Weis et al., 1991). The tissues were then postfixed in glutaraldehyde followed by osmium tetroxide, dehydrated in a series of ethanols, and embedded in Epon for viewing without uranyl or lead staining.

Stab wounds. Adult mice were anesthetized with Avertin, the dorsal surface of the brain exposed, and a stab wound made in the right cerebral hemisphere by insertion of a 25 gauge needle from the dorsal surface to the ventral surface of the brain. The needle was then withdrawn, the skin incision closed with wound clips, and the animals allowed to recover on a warming plate. The mice were killed at $48 \mathrm{hr}$ postsurgery for analysis of $l a c Z$ expression in the operated versus unoperated side of the brain.

Animal use. All animal protocols were approved by the Institutional Animal Care and Use Committee of the University of Wisconsin-Madison.

\section{Results}

Generation of transgenic mice. The gfa2-lac Z transgene is diagramed in Figure 1. The $g f a 2$ segment spans base pairs (bp) -2163 to +47 relative to the transcriptional start site of the hGFAP gene, and has the normal protein-initiating ATG at bp +15 converted to TTG by site-directed mutagenesis (Besnard et al., 1991). To facilitate analysis, two versions of the transgene were used: one that produces the standard cytoplasmic enzyme, and one that targets the enzyme to the nucleus (Mercer et al., 1991).

Transgenic mice were generated by microinjection of fertilized mouse eggs. Ten of the pups were identified as transgenic by polymerase chain reaction (PCR) analysis of tail DNA. Eight of the 10 founders produced breeding lines, and offspring in these lines were tested for expression of the lac $Z$ transgene by screening slices of brain with X-gal histochemistry. Six of the eight transgenic lines expressed lac $Z$ in the brain (Fig. 2, Table 1).

Tissue- and cell-specific expression of the transgene. Two cell types other than astrocytes known to synthesize GFAP are non-
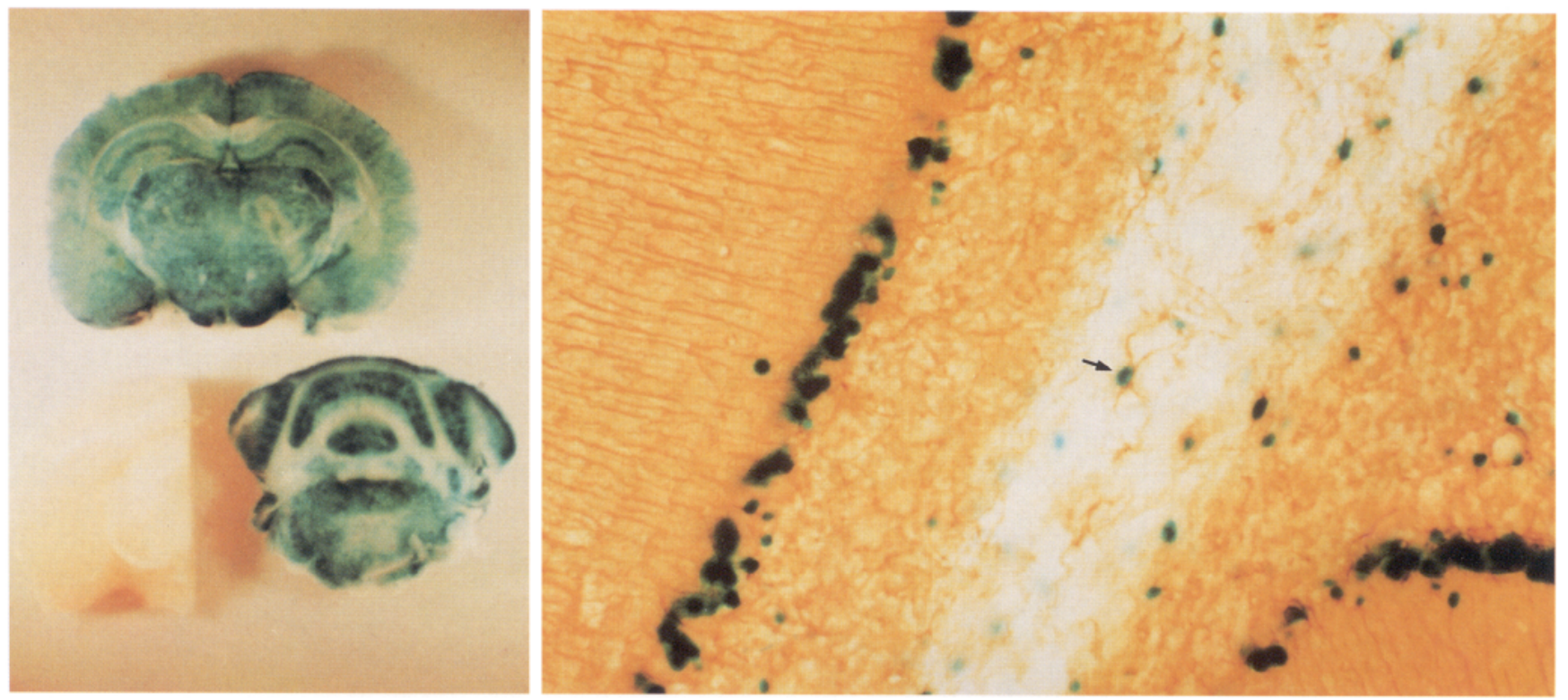

Figure 2. Brain slices of gfa2-lacZ transgenic mouse and nontransgenic control stained for lacZ: cranial (top) and caudal (lower right) transverse slices of the brain of an adult transgenic mouse (6-4 line), and a cranial transverse slice from an adult nontransgenic control (lower left) were stained for lac Z activity with X-gal.

Figure 3. Double staining for GFAP and lacZ. GFAP immunohistochemistry was performed on an X-gal-stained vibratome section (50 $\mu$ m) of cerebellum from a 31/2-month-old transgenic mouse of the 7-1 line (nuclear lacZ). The GFAP immunoreactivity of the radial processes extending to the pial surface from the area of X-gal-positive nuclei is the result expected for Bergmann glia. The arrow points to one of several isolated distinctly double-labeled cells within the white matter of the cerebellum. Magnification, $234 \times$. 


\begin{tabular}{lll}
\hline Table 1. Transgenic founder mice & \\
Transgene & Founders & Expression \\
\hline Cytoplasmic lac & $6-1$ & - \\
& $6-2$ & - \\
& $6-3$ & + \\
& $6-4$ & + \\
Nuclear lacZ & $6-5$ & + \\
& $7-1$ & + \\
& $7-2$ & + \\
$7-3$ & No offspring \\
& $7-4$ & No offspring \\
& $7-5$ & +
\end{tabular}

Transgenic founders were identified by PCR analysis of tail sample DNA. Expression was determined by staining brain slices with X-gal histochemistry.

\begin{tabular}{|c|c|c|c|c|c|c|}
\hline Mice & Brain & Kidney & Liver & Spleen & Heart & Lung \\
\hline Control & 0.2 & 0.8 & 0.2 & 0.6 & $<0.1$ & $<0.1$ \\
\hline $6-3 \mathrm{H}^{a}$ & 4.3 & 0.8 & 0.1 & 0.4 & 0.1 & 0.1 \\
\hline $6-3 \mathrm{H}$ & 17.3 & 0.7 & 0,2 & 0.5 & $<0.1$ & 0.1 \\
\hline $6-4-41$ & 15.9 & 0.4 & 0.1 & 0.6 & 0.1 & 0.1 \\
\hline $6-4-42$ & 14.2 & 0.9 & 0.2 & 0.8 & 0.1 & 0.1 \\
\hline $7-1-17$ & 5.1 & 0.2 & $<0.1$ & 0.2 & $<0.1$ & $<0.1$ \\
\hline $7-2-24^{b}$ & 8.4 & 0.5 & 0.1 & 0.3 & 0.1 & 0.1 \\
\hline $7-2-25$ & 8.3 & 0.6 & $<0.1$ & 0.4 & 0.1 & 0.2 \\
\hline
\end{tabular}

Tissues from adult ( $>1$-month-old) animals were assayed for $\beta$-galactosidase using the solution assay as described in Materials and Methods. Values presented are averages of duplicate assays. Mice of the same line were littermates.

"6-3 $\mathrm{H}$ mice are homozygous for the transgene. The difference in values for the two 6-3 $\mathrm{H}$ mice reflects a general variability in expression seen for the 6-3 line.

"Both 7-2-24 and 7-2-25 are hemizygous females (see below).

proof of these assignments has not been pursued. We also note that expression of the 7-2 line (nuclear lac Z) in the retina was unexpected as the host strain (B6SJLF1) has unreactive Müller cells.

Histochemical staining proved unsuitable for a general survey of other tissues because of high background staining in some tissues (particularly kidney) of control mice. Consequently, a more specific solution assay was used instead of histochemical staining. As shown in Table 2, the only tissue of the transgenic animals to display $\beta$-galactosidase activity significantly greater than the nontransgenic control was the brain, for which activity was up to 80 times higher than the control.

Transgene expression was prominent in gray and white matter of the cerebellum, brainstem, and cerebral hemispheres (Fig. 2). In the cerebellum there was distinct labeling of Bergmann glial

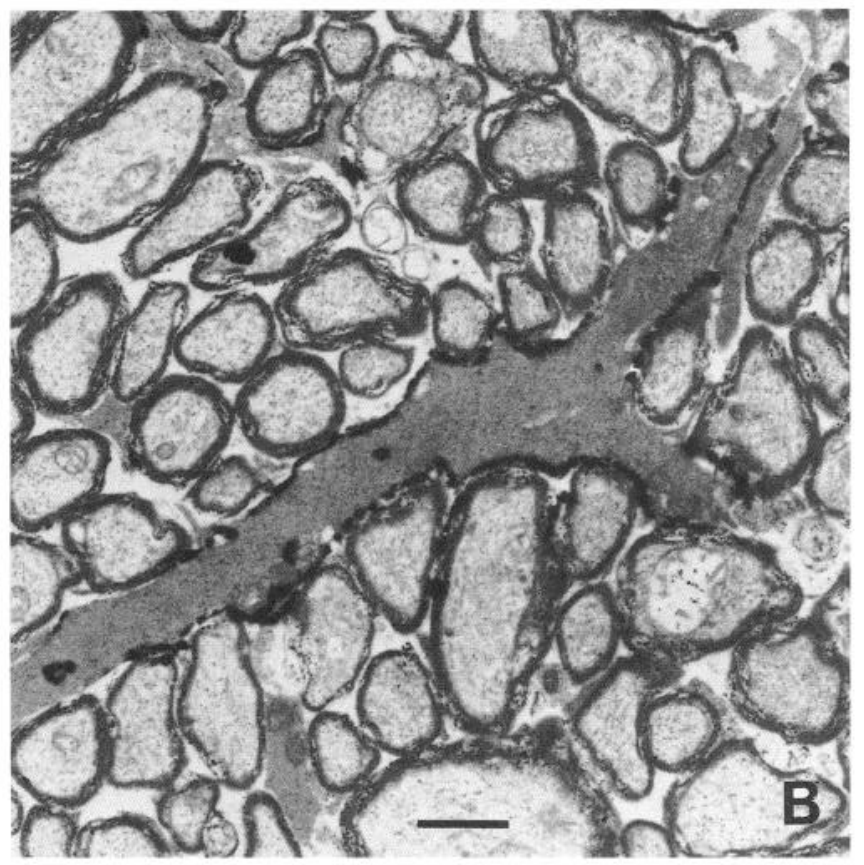

Figure 4. Transgenic optic nerve stained for lacZ. Electron micrographs were made of transverse sections of optic nerve from transgenic mice and stained using Bluo-gal. A, A labeled astrocyte (upper left) and an unlabeled oligodendrocyte (lower right) of a 3-month-old mouse of the 7-2 line (nuclear lacZ) showing prominent staining of the nuclear membrane of the astrocyte. $B$, Astrocyte process of a 6-month-old mouse of the 6-4 line (cytoplasmic lac $Z$ ) showing prominent subplasmalemmal staining. Scale bars, $1 \mu \mathrm{m}$. 


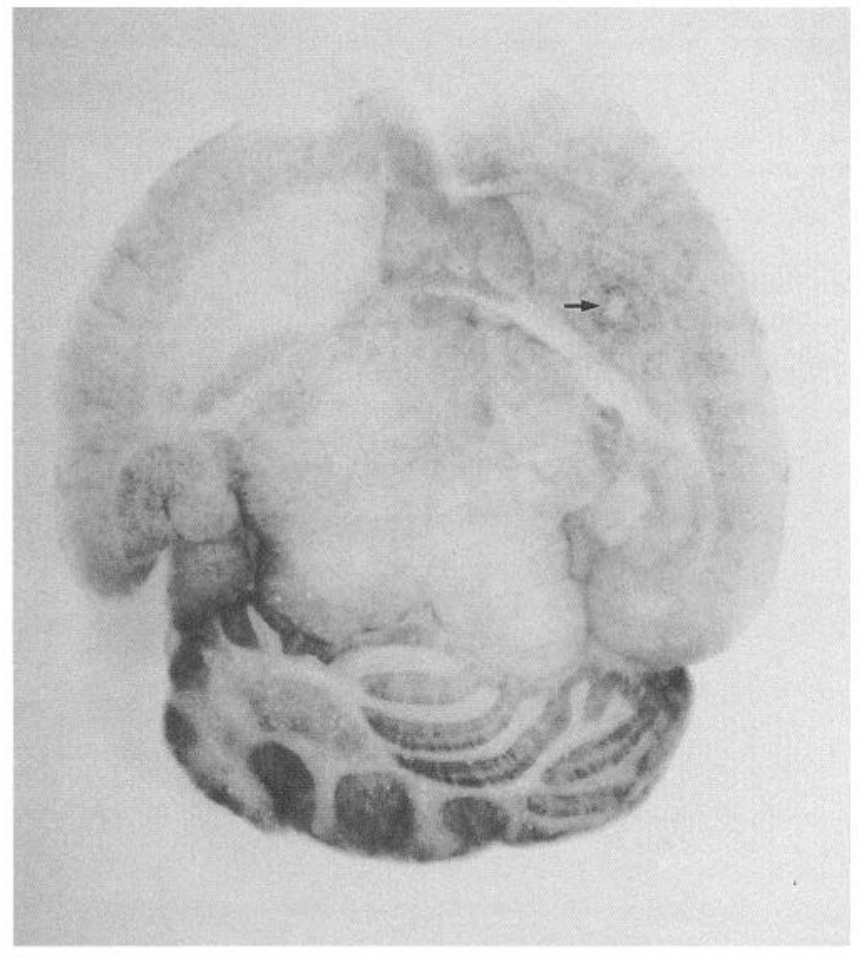

Figure 5. Response of the transgene to a stab wound. A horizontal slice of brain from a 2-month-old transgenic mouse (6-3 line) was stained for $l a c Z$ with $\mathrm{X}$-gal $48 \mathrm{hr}$ following a stab wound to the right cerebral hemisphere (indicated by arrow). Note the increased X-gal staining in the area immediately surrounding the needle track, compared to the contralateral striatum. The striatum was selected for analysis as it typically shows a relatively low level of GFAP (Kálmán and Hajós, 1989), permitting the reactive response to be easily detected over background.

cell bodies and their radial processes in the molecular layers. This pattern of staining was the same in each of the six lines tested, although there were variations in staining intensity $\mathrm{Ta}$ ble 2 ; the two lines not listed, 6-5 and 7-5, stained less strongly than the others). To ascertain whether the transgene expression in the brain was restricted to astrocytes, tissue slices stained with X-gal from mice carrying the nuclear form of the lacZ transgene were also stained for GFAP by immunohistochemistry. Many cells showed X-gal-positive nuclei surrounded by GFAP-immunoreactive processes (Fig. 3).

While the double-labeling experiments demonstrated that at least some X-gal-positive cells were astrocytes, some X-galpositive cells were negative for GFAP, particularly in the centers of the slices. Since incomplete penetration by the immunoreagents could produce such results, we performed ultrastructural analyses on optic nerves. Cells expressing the transgene were identified by staining with the $\beta$-galactosidase substrate Bluogal, which gives rise to a discrete, electrodense reaction product (Weis et al., 1991), and cell types were determined morphologically. To ensure objectivity, the electron micrographs were coded and then analyzed by an independent expert (Dr. Ian D. Duncan, University of Wisconsin-Madison). Three different lines of transgenic mice were examined, and over 50 astrocytes and oligodendrocytes identified. In each of the lines, most, but not all, of the astrocytes were stained by the Bluo-gal, whereas none of the other cell types were stained. Typical results are shown in Figure 4. In summary, these data show that $2.2 \mathrm{~kb}$ of $5^{\prime}$ flanking sequences from the hGFAP gene contain sufficient reg-

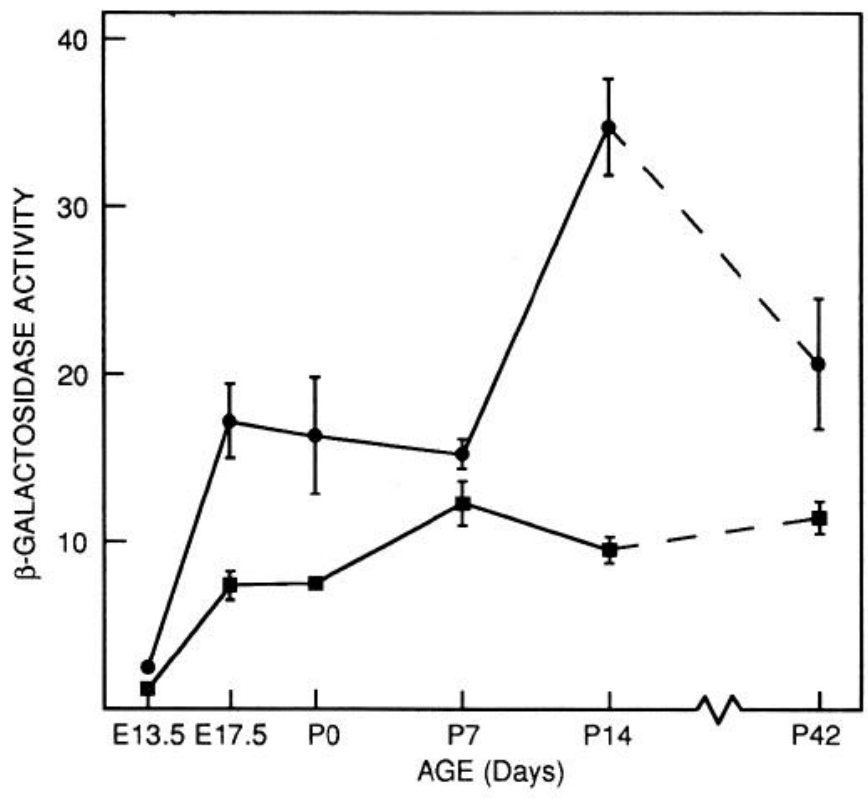

Figure 6. Developmental regulation of $l a c Z$ activity in two transgenic lines. Four or five brains were collected at each of the indicated time points (except entire heads for E13.5) from animals of the 6-4 (๑) and 7-2 (ם) lines. $\beta$-Galactosidase activity was determined on tissue extracts by the MUG solution assay as described in Materials and Methods. All 7-2 animals used were hemizygous females (see below); 6-4 animals were of either sex.

ulatory elements to direct astrocyte-specific expression in transgenic mice.

Transgene response to injury. Astrocyte expression of GFAP increases markedly in response to brain injury as part of the process of reactive gliosis. We therefore wished to see whether the regulatory elements responsible for this upregulation were present in the $g f a 2-l a c Z$ transgene. A common model for studying reactive astrocytosis is infliction of a stab wound into the cerebral cortex of an anesthetized animal, which causes a rapid increase in GFAP mRNA and protein in reactive astrocytes (Cavanagh, 1970; Bignami and Dahl, 1976; Latov et al., 1979; Mathewson and Berry, 1985; Topp et al., 1989). We subjected mice carrying the $g f a 2-l a c Z$ transgenes to stab wounds and stained their brains for lac Z activity $48 \mathrm{hr}$ later. As shown in Figure 5, there was a marked increase in X-gal staining in the immediate vicinity of the stab wound. Similar results were obtained with all three of the $g f a 2-l a c Z$ lines that were analyzed.

Developmental regulation of the transgene. Onset of endogenous GFAP expression in the mouse coincides with the period of astroglial differentiation and proliferation during late gestation and the first week after birth. Typically, the abundance of GFAP mRNA is found to increase until 1-2 weeks after birth, and then to decline slowly (Lewis and Cowan, 1985; Tardy et al., 1989). To determine if the expression of the $g$ fa2-lac $Z$ transgene shows similar developmental regulation, we assayed wholebrain extracts of mice whose ages ranged from embryonic day 13.5 (E13.5) through adulthood. Mice of two separate lines (6-4 and 7-2) were assayed with their nontransgenic littermates serving as controls. Although differing from each other in details, the postnatal patterns of expression of the two transgenes fit the general profile for the endogenous GFAP gene (Fig. 6). On the other hand, transgene activity was already detectable in the fetus at E13.5, whereas the earliest reported detection of GFAP mRNA 


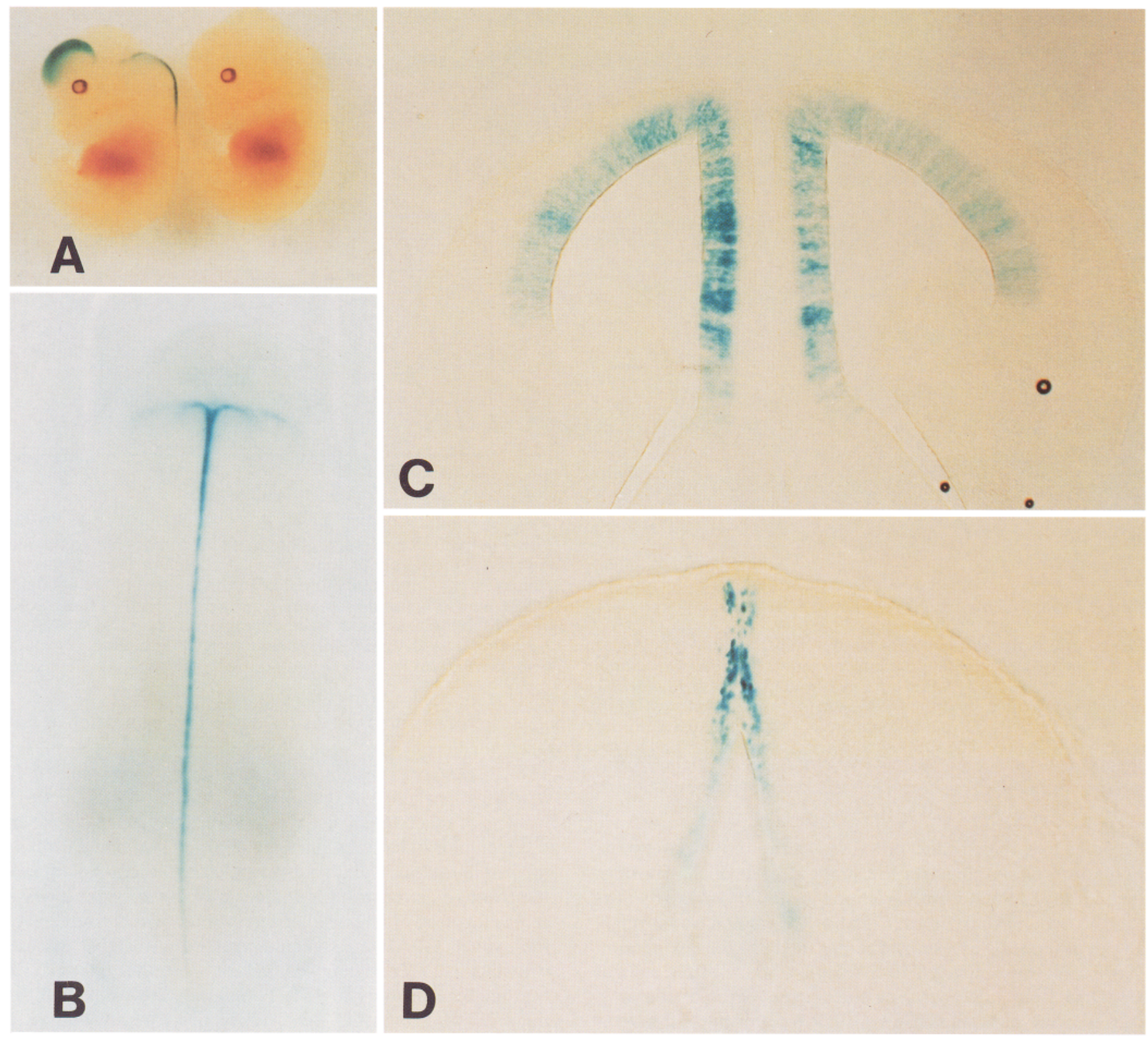

Figure 7. Fetal expression of the transgene. Whole embryos $(A, B)$ or vibratome sections $(C, D)$ of E13.5 hemizygous females of the 7-2 line were stained for lacZ activity with X-gal histochemistry. $A$, Lateral view of transgenic (left) and nontransgenic (right) littermates. $B$, Dorsal view. The dorsal midline streak was seen at E13.5 in each of the five lines examined. In some specimens, the staining was incomplete in the midthoracic region. The head is at the top of the field. $C$, Vibratome section $(100 \mu \mathrm{m})$ through the telencephalon. X-gal reaction product is seen in the ventricular zone of the telencephalon. Magnification, $46 \times . D$, Vibratome section $(100 \mu \mathrm{m})$ through the developing spinal cord. X-gal reaction product is located along the roof plate of the dorsal midline and around the dorsal half of the central canal. Magnification, $114 \times$.

or protein is about E16.5 for both the mouse (Bovolenta et al., 1987) and the rat (Hirano and Goldman, 1988; Landry et al., 1990).

Developmental topography of transgene expression. To localize further the transgene-expressing cells during fetal stages, whole fetuses or brain sections were collected from E10.5 through the postnatal period and stained with X-gal. The gfa2-lacZ transgene was first expressed between E12.5 and E13.5 in each of five lines tested. All of these lines showed a similar pattern, which included staining of the telencephalon, hindbrain, and along the dorsal midline of the spinal cord (Fig. 7A,B). Within these regions, staining was localized to the ventricular zone of the developing telencephalon and hippocampus (Fig. $7 \mathrm{C}$ ), and in the developing spinal cord to the cells located dorsally and immediately around the central canal and extending into the region of the developing dorsal median sulcus (Fig. $7 D$ ). In addition, one of these lines (6-4) also showed expression in chondrocytes at E13.5. By E17.5, staining was found throughout the brain, and was particularly intense in the developing cerebellum and ventricular surfaces (data not shown). At later time points, staining became more uniform, and occurred in both gray and white matter.

$X$-inactivation of the transgene in the 7-2 line. Pedigree analysis of the transgenic lines showed that the transgene of the 7-2 
line was X-linked (data not shown). We considered that this particular transgene might therefore be susceptible to $\mathrm{X}$-inactivation, whereby females compensate for potential gene dosage effects by random inactivation of one or the other X-chromosome. Consistent with this expectation, solution assays showed that the brains of male 7-2 mice had twice the levels of bacterial $\beta$-galactosidase activity as those from age-matched hemizygous females (Fig. 8). In some cases, random X-chromosome inactivation results in mosaic patches of tissues in which all cells in a given patch derive from the same precursor that had already undergone $\mathrm{X}$-inactivation. We examined slices and sections of brain from female 7-2 mice of various ages at a resolution that could detect patches as small as 25 cells, but found no evidence for mosaic expression (data not shown).

\section{Discussion}

The primary goal of this study was to determine if the $2.2 \mathrm{kh}$ 5 '-flanking region ( $g f a 2)$ of the hGFAP gene identified by in vitro studies to direct astrocyte-specific expression did so in the transgenic mouse. The transgenic animal represents a much stricter test system for assaying gene regulation since the transgene is present in all cell types and is exposed to normal developmental and environmental influences. In several cases, the specificity of gene expression has differed markedly when the same constructs were tested both in cell lines and in transgenic mice (Dente et al., 1988; Vassar et al., 1989; Zimmerman et al., 1990). Our finding that the $g f a 2-l a c Z$ transgene is expressed, and that this expression is almost exclusively in astrocytes, justifies focusing on the $g f a 2$ region for further dissection of the critical regulatory elements, and also provides a simple means for directing expression of other genes of intcrest to astrocytes.

While the endogenous GFAP gene is expressed most strongly in astrocytes, low levels of GFAP or GFAP-like immunoreactivity have been described in several other cell types (Jessen and Mirsky, 1984; Jessen et al., 1984; Gard et al., 1985; Hatfield et al., 1985; Kasper and Stosiek, 1990; Moll et al., 1991; Sarthy et al., 1991; Feinstein et al., 1992). Two of these other cell types that have been shown definitely to express GFAP are reactive retinal Müller cells and nonmyelinating Schwann cells (Jessen and Mirsky, 1984; Sarthy and Fu, 1989; Feinstein et al., 1992). However, only one line (7-2) of the six that express the lac $Z$ transgene in the brain also expresses it in the retina and peripheral nerves. While we have not proved that the expressing cells in these tissues are actually Müller cells and Schwann cells, this is a reasonable assumption given the known presence of GFAP in these cell types, and the absence of 7-2 transgene activity in non-GFAP-containing tissues. The failure to detect transgene activity in retina and peripheral nerve in the other lines cannot be attributed to a general quantitative effect, as CNS activity of the 7-2 transgene was comparable to that of the other five lines, and its expression in the retina and peripheral nerve, while low, was readily detectable. Instead, activity in these other tissues probably depends on the integration site of the transgene, which suggests that Müller cells and Schwann cells utilize a set of GFAP regulatory regions in the $g f a 2$ segment that differs from and is more integration site dependent than that used in astrocytes. Alternatively, a critical region for expression in these cells may lie outside the gfa2 fragment and be fortuitously supplied by insert-flanking host DNA. The recent finding that the major site for initiation of GFAP mRNA in Schwann cells is distinct from that in astrocytes (Feinstein et al., 1992) may reflect such a regulatory difference.

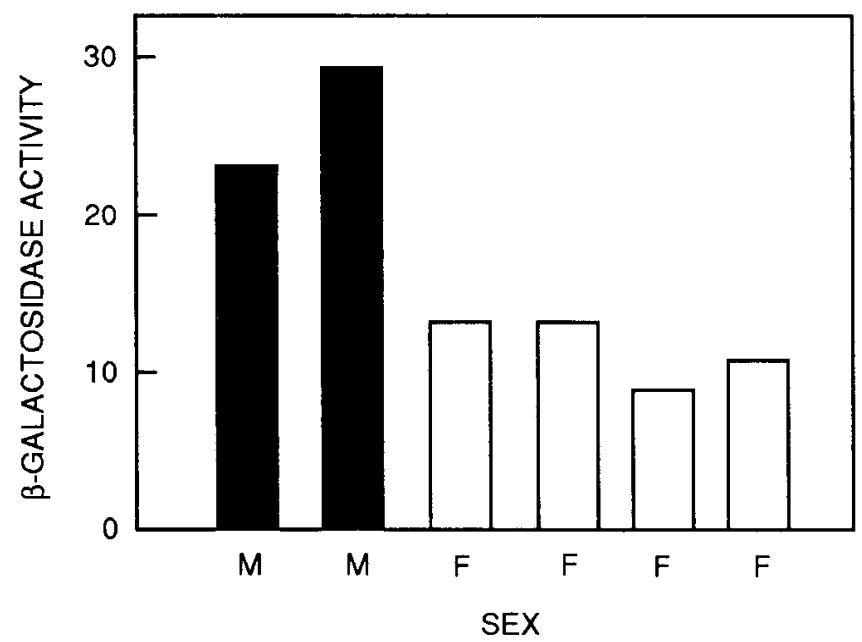

Figure 8. Comparison of the brain lac $Z$ activity of males versus females of transgenic line $7-2$. The lac $Z$ activity was determined by the MUG solution assay on 6-week-old individual males $(M)$ and females $(F)$ of the 7-2 line (littermates).

The absence of peripheral nerve expression was also noted in an earlier transgenic model of Mucke et al. (1991), in which the $l a c Z$ reporter gene was inserted into the first exon of a $13.2 \mathrm{~kb}$ genomic clone of the mouse GFAP gene. No data were presented concerning expression of this transgene in retinal Müller cells. The mouse genomic clone used extended from approximately $2.0 \mathrm{~kb}$ upstream of the RNA start site (similar to the $5^{\prime}$ end of the $g f a 2$ fragment) to about $1.4 \mathrm{~kb} 3^{\prime}$ of the last exon. Hence, inclusion of all the exons and introns of the GFAP gene was no more conducive to expression in Schwann cells than the $2.2 \mathrm{~kb}$ of the $g f a 2$ fragment used here. Possibly, sequences farther upstream than $-2.2 \mathrm{~kb}$ are required for consistent expression in Schwann cells.

The only other nonastrocytic transgene expression observed was in chondroblasts in the 6-4 line. It is unclear whether this represents appropriate expression that is especially sensitive to the site of integration, or is simply an artifact of this particular line. Expression of GFAP immunoreactivity in chondroblasts has been reported (Kasper and Stosiek, 1990).

A functional intronic element was reported by Sarkar and Cowan (1991), who found that a segment of the first intron of the murine gene was required to suppress expression in HeLa cells. Our transgene did not include the first intron of the hGFAP gene, yet showed no general ectopic expression. In addition, when Schönrich et al. (1991) used a similar 5' region of the mouse GFAP gene to drive expression of an $\mathrm{H}-2 \mathrm{~K}^{\mathrm{b}}$ transgene, they also found expression to be primarily in the brain. These results suggest that the first intron of the human and mouse GFAP genes does not contain a significant negative regulatory element.

The upregulation of the $g f a 2-l a c Z$ transgene in response to a stab wound shows that it contains one or more regulatory elements activated during reactive gliosis. It is possible that additional elements that participate in GFAP upregulation lie outside the $2.2 \mathrm{~kb} g f a 2$ segment; for example, the data presented by Mucke et al. (1991) suggest that their $13.2 \mathrm{~kb}$ genomic clone of GFAP may mediate a stronger response. However, the localization to the $g f a 2$ segment of at least one reactive site will facilitate the precise identification of a transcriptional element activated during gliosis, which in turn should provide important 
insights into rcgulatory mechanisms operating during this process.

Expression of the $g f a 2-l a c Z$ transgene in postnatal mice appears to be restricted to astrocytes and to follow a time course similar to the endogenous gene (Lewis and Cowan, 1985; Choi, 1988; Tardy et al., 1989, 1990; Landry et al., 1990; Lazarini et al., 1991; Li and Bartlett, 1991). Prenatally, however, the transgene is expressed by E12.5 to E13.5, while the earliest stage reported for expression of the endogenous GFAP gene is about E16 (Bovolenta et al., 1987; Hirano and Goldman, 1988; Landry et al., 1990). On the other hand, the position of the stained cells is consistent with that of radial glia, which are first seen in the mouse at about this time (Choi, 1988). In rodents, radial glia express only vimentin and nestin (Schnitzer et al., 1981; Hockfield and McKay, 1985) whereas primate radial glia also express GFAP (Choi, 1981). In humans, GFAP-positive radial glia are seen during the first third of gestation (Choi and Lapham, 1978; Levitt and Rakic, 1980; Aloisi et al., 1992). If the transgene expression seen by E13.5 is in radial glia, then it is in only a subset of these cells, as the distribution of X-gal staining appears to be more restricted than that reported for radial glia using the antibody marker RC1 (Edwards et al., 1990).

Several hypotheses can be proposed to explain this early expression of the gfa2-lacZ transgene. First, the histochemical detection of the lac $Z$ reporter gene activity may be a more sensitive indicator of GFAP transcriptional activity than previously used methods for detecting expression of the endogenous gene. Second, a regulatory element outside the gfa 2 fragment may normally suppress prenatal expression of the gene. Third, the human and murine genes may differ in their regulatory elements, despite the high degree of homology that has been found (Besnard et al., 1991), so in our transgenic system the human pattern of developmental regulation is conferred through use of the hGFAP promoter.

Pedigree analysis in the 7-2 line demonstrated that the transgene had integrated into the X-chromosome. Quantitative comparisons of bacterial $\beta$-galactosidase activity in brain extracts of hemizygous females to that in males showed that the males had almost exactly twice the levels of the females. These data are consistent with the hypothesis that the homizygous females represented a mosaic of transgene-expressing and nonexpressing cells, as predicted by the Lyon hypothesis. In studies of X-linked myelin mutants of proteolipid protein, analogous mosaicism in the oligodendrocytes appears as large, easily visible patches (Skoff and Montgomery, 1981; Duncan et al., 1993). However, tissues from hemizygous mice of the 7-2 line showed no evidence of mosaicism in staining with X-gal. Either each X-inactivated progenitor gives rise to only a very small patch of mature astrocytes, or there is extensive migration and intermingling of astrocytes following their formation. In three previous studies of transgenes that had integrated into the X-chromosome, expression patterns showed either random inactivation (Krumlauf et al., 1986), partial inactivation (Wu et al., 1992), or escape from inactivation (Goldman et al., 1987).

In summary, the data presented here show that a $2.2 \mathrm{~kb}$ segment of 5'-flanking DNA from the hGFAP gene is sufficient both to direct astrocyte-specific transcription and to upregulate activity in gliosis. The data also suggest that nonastrocytic cells use a different set of GFAP regulatory elements to express GFAP. The specificity shown by the $g f a 2$ fragment justifies focusing further on this segment to identify specific regulatory elements (Masood et al., 1993). It also provides a simple procedure for directing expression of other genes in astrocytes in order to study brain function. Such studies may ultimately allow modification of the astrocyte response to injury in the brain, and amelioration of the course of neurologic diseases.

\section{References}

Aloisi F, Giampaolo A, Russo G, Peschle C, Levi G (1992) Developmental appearance, antigenic profile and proliferation of glial cells of the human embryonic spinal cord: an immunocytochemical study using dissociated cultured cells. Glia 5:171-181.

Balcarek JM, Cowan NJ (1985) Structure of the mouse glial fibrillary acidic protein gene: implications for the evolution of the intermediate filament gene family. Nucleic Acids Res 13:5527-5543.

Besnard F, Brenner M, Nakatani Y, Chao R, Purohit HJ, Freese E (1991) Multiple interacting sites regulate astrocyte-specific transcription of the human gene for glial fibrillary acidic protein. J Biol Chem 266:18877-18883.

Bignami A, Dahl D (1976) The astroglial response to stabbing. Immunofluorescence studics with antibodies to astrocyte-specific protein (GFA) in mammalian and submammalian species. Neuropathol Appl Neurobiol 2:99-110.

Bovolenta P, Liem RKH, Mason CA (1984) Development of cerebellar astroglia: transitions in form and cytoskeletal content. Dev Biol 102:248-259.

Bovolenta P, Liem RKH, Mason CA (1987) Glial filament protein expression in astroglia in the mouse visual pathway. Dev Brain Res 33:113-126.

Brenner M, Lampel K, Nakatani Y, Mill J, Banner C, Mearow K, Dohadwala M, Lipsky R, Freese E (1990) Characterization of human cDNA and genomic clones for glial fibrillary acidic protein. Mol Brain Res 7:277-286.

Brinster RL, Chen HY, Trumbauer ME, Yagle MK, Palmiter RD (1985) Factors affecting the efficiency of introducing forcign gencs into mice by microinjecting eggs. Proc Natl Acad Sci USA 82:4438-4442.

Cavanagh JB (1970) The proliferation of astrocytes around a needle wound in the rat brain. J Anat 106:471-487.

Choi BH (1981) Radial glia of developing human fetal spinal cord: Golgi immuno-histochemical and electron microscopic study. Dev Brain Kes 1:249-267.

Choi BH (1988) Prenatal gliogenesis in the developing cerebrum of the mouse. Glia 1:308-316.

Choi BH, Lapham LW (1978) Radial glia in the human fetal cerebrum: a combined Golgi, immunofluorescent and electron microscopic study. Brain Res 148:295-311.

Dahl D (1981) The vimentin-GFA protein transition in rat neuroglia cytoskeleton occurs at the time of myelination. J Neurosci Res 6:741748.

Dente L, Ruther U, Tripodi M, Wagner EF, Cortese R (1988) Expression of human 1-acid glycoprotein genes in cultured cells and in transgenic mice. Genes Dev 2:259-266.

Duncan ID, Jackson KF, Hammang JP, Marren D, Hoffman R (1993) Development of myelin mosaicism in the optic nerve of heterozygotes of the X-linked myelin deficient $(m d)$ rat mutant. Dev Biol 157:334347.

Edwards MA, Yamamoto M, Caviness VS (1990) Organization of radial glia and related cells in the developing murine CNS. An analysis based upon a new monoclonal antibody marker. Neuroscience 36 : 121-144.

Eng LF (1988) Regulation of glial intermediate filaments in astrogliosis. In: The biochemical pathology of astrocytes (Norenberg MD, Hertz L, Schousboe A, eds), pp 79-90. New York: Liss.

Fedoroff S, Vernadakis A, eds (1986a) Astrocytes: development, morphology, and regional specialization of astrocytes, Vol 1. New York: Academic.

Fedoroff S, Vernadakis A, eds (1986b) Astrocytes: cell biology and pathology of astrocytes, Vol 3. New York: Academic.

Feinstein DL, Weinmaster GA, Milner RJ (1992) Isolation of cDNA clones encoding rat glial fibrillary acidic protein: expression in astrocytes and in Schwann cells. J Neurosci Res 32:1-14.

Gard AL, White FP, Dutton GR (1985) Extraneural glial fibrillary acidic protein (GFAP) immunoreactivity in perisinusoidal stellate cells of rat liver. J Neuroimmunol 8:359-375.

Goldman JE, Chiu FC (1984) Growth kinetics, cell shape, and the cytoskeleton of primary astrocyte cultures. J Neurochem 42:175-184. 
Goldman MA, Stokes KR, Idzerda RL, McKnight GS, Hammer RE, Brinster RL, Gartler SM (1987) A chicken transferrin gene in transgenic mice escapes X-chromosome inactivation. Science 236:593595.

Hatfield JS, Skoff RP, Maisel H, Eng L, Bigner DD (1985) The lens epithelium contains glial fibrillary acidic protein (GFAP). J Neuroimmunol 8:347-357.

Hirano M, Goldman JE (1988) Gliogenesis in rat spinal cord: evidence for origin of astrocytes and oligodendrocytes from radial precursors. J Neurosci Res 21:155-167.

Hockfield S, McKay RDG (1985) Identification of major cell classes in the developing mammalian nervous system. J Neurosci 5:33103328.

Jessen KR, Mirsky R (1984) Nonmyelin-forming Schwann cells coexpress surface proteins and intermediate filaments not found in myelinforming cells: a study of Ran-2, A5E3 antigen and glial fibrillary acidic protein. J Neurocytol 13:923-934.

Jessen KR, Thorpe R, Mirsky R (1984) Molecular identity, distribution and hetero-geneity of glial fibrillary acidic protein: an immunoblotting and immunohistochemical study of Schwann cells, satellite cells, enteric glia and astrocytes. J Neurocytol 13:187-200.

Kálmán M, Hajós F (1989) Distribution of glial fibrillary acidic protein (GFAP)-immunoreactive astrocytes in the rat brain. I. Forebrain. Exp Brain Res 78:147-163.

Kasper M, Stosiek P (1990) Detection of GFAP in vertebral fibrocartilage in human fetal and newborn tissue. Acta Histochem 88:2527.

Krumlauf R, Chapman VM, Hammer RE, Brinster R, Tilghman SM (1986) Differential expression of $\alpha$-fetoprotein genes on the inactive $\mathrm{X}$ chromosome in extraembryonic and somatic tissues of a transgenic mouse line. Nature 319:224-226.

Landry CF, Ivy GO, Brown IR (1990) Developmental expression of glial fibrillary acidic protein mRNA in the rat brain analyzed by in situ hybridization. J Neurosci Res 25:194-203.

Latov N, Nilaver G, Zimmerman EA, Johnson WG, Silverman AJ, Defendini R, Cote L (1979) Fibrillary astrocytes proliferate in response to brain injury. Dev Biol 72:381-384.

Lazarini F, Deslys JP, Dormont D (1991) Regulation of the glial fibrillary acidic protein, beta actin and prion protein mRNAs during brain development in mouse. Mol Brain Res 10:343-346.

Levitt P, Rakic P (1980) Immunoperoxidase localization of glial fibrillary acidic protein in radial glial cells and astrocytes of the developing rhesus monkey brain. J Comp Neurol 193:815-840.

Lewis SA, Cowan NJ (1985) Temporal expression of mouse glial fibrillary acidic protein mRNA studied by a rapid in situ hybridization procedure. J Neurochem 45:913-919.

Li XS, Bartlett WP (1991) Developmental expression of glial fibrillary acidic protein and glutamine synthetase mRNAs in normal and jimpy mice. Mol Brain Res 9:313-317.

Masood K, Besnard F, Su Y, Brenner M (1993) Analysis of a segment of the human glial fibrillary acidic protein gene that directs astrocytespecific transcription. J Neurochem 61:160-166.

Mathewson AJ, Berry M (1985) Observations on the astrocyte response to a cerebral stab wound in adult rats. Brain Res 327:61-69.

Mercer EH, Hoyle GW, Kapur RP, Brinster RL, Palmiter RD (1991) The dopamine $\beta$-hydroxylase gene promoter directs expression of $E$. coli lacZ to sympathetic and other neurons in adult transgenic mice. Neuron 7:703-716.

Miura M, Tamura T, Mikoshiba K (1990) Cell-specific expression of the mouse glial fibrillary acidic protein gene: identification of the cisand trans-acting promoter elements for astrocyte-specific expression. J Neurochem 55:1180-1188.

Moll R, Hage C, Thoenes W (1991) Expression of intermediate filament proteins in fetal and adult human kidney: modulations of intermediate filament patterns during development and in damaged tissue. Lab Invest 65:74-86.

Morrison RS, de Vellis J, Lee YL, Bradshaw RA, Eng LF (1985) Hormones and growth factors induce the synthesis of glial fibrillary acidic protein in rat brain astrocytes. J Neurosci Res 14:167-176.
Mucke L, Oldstone MBA, Morris JC, Nerenherg MI (1991) Rapid activation of astrocyte-specific expression of GFAP-lac $Z$ transgene by focal injury. New Biol 3:465-474.

Nakatani Y, Horikoshi M, Brenner M, Yamamoto T, Besnard F, Roeder RG, Freese E (1990) A downstream initiation element required for efficient TATA box binding and in vitro function of TFIID. Nature 348 :86-88.binding and in vitro function of TFIID. Nature 348:8688 .

Norenberg MD, Hertz L, Schousboe A (1988) The biochemical pathology of astrocytes. New York: Liss.

O'Callaghan JP, Brinton RE, McEwen BS (1991) Glucocorticoids regulate the synthesis of glial fibrillary acidic protein in intact and adrenalectomized rats but do not affect its expression following brain injury. J Neurochem 57:860-869.

Roderick TH, Guidi JH (1989) Strain distribution of polymorphic variants. In: Genetic variants and strains of the laboratory mouse, $2 \mathrm{~d}$ ed (Lyon MF, Searle AG, eds), pp 663-772. Oxford: Oxford UP.

Sarid J (1991) Identification of a cis-acting positive regulatory element of the glial fibrillary acidic protein gene. J Neurosci Res 28:217-228.

Sarkar S, Cowan NJ (1991) Intragenic sequences affect the expression of the gene encoding glial fibrillary acidic protein. J Neurochem 57: 675-684.

Sarthy PV, Fu M (1989) Transcriptional activation of an intermediate filament protein gene in mice with retinal dystrophy. DNA 8:437446.

Sarthy PV, Fu M, Huang J (1991) Developmental expression of the glial fibrillary acidic protein (GFAP) gene in the mouse retina. Cell Mol Neurobiol 11:623-637.

Schnitzer J, Franke WW, Schachner M (1981) Immunocytochemical demonstration of vimentin in astrocytes and ependymal cells of developing and adult mouse nervous system. J Cell Biol 90:435-447.

Schönrich G, Kalinke U, Momburg F, Malissen M, Schmitt-Verhulst A-M, Malissen B, Hämmerling GJ, Arnold B (1991) Down-regulation of $T$ cell receptors on self-reactive $T$ cells as a novel mechanism for extrathymic tolerance induction. Cell 65:293-304.

Shafit-Zagardo B, Kume-Iwaki A, Goldman JE (1988) Astrocytes regulate GFAP mRNA levels by cyclic AMP and protein kinase C-dependent mechanisms. Glia 1:346-354

Skoff RP, Montgomery IN (1981) Expression of mosaicism in females heterozygous for jimpy. Brain Res 212:175-181.

Tardy M, Fages C, Riol H, LePrince G, Rataboul P, Charriere-Bertrand C, Nunez J (1989) Developmental expression of the glial fibrillary acidic protein mRNA in the central nervous system and in cultured astrocytes. J Neurochem 52:162-167.

Tardy M, Fages C, Le Prince G, Rolland B, Nunez J (1990) Regulation of the glial fibrillary acidic protein (GFAP) and of its encoding mRNA in the developing brain and in cultured astrocytes. Adv Exp Med Biol 265:41-52.

Topp KS, Faddi BT, Vijayan VK (1989) Trauma-induced proliferation of astrocytes in the brains of young and aged rats. Glia 2:201-211.

Vandaele S, Nordquist DT, Feddersen RM, Tretjakoff I, Peterson AC, Orr HT (1991) Purkinje cell protein-2 regulatory regions and transgene expression in cerebellar compartments. Genes Dev 5:1136-1148.

Vassar R, Rosenberg M, Ross S, Tyner A, Fuchs E (1989) Tissuespecific and differentiation-specific expression of a human K14 keratin gene in transgenic mice. Proc Natl Acad Sci USA 86:1563-1567.

Weis I, Fine SM, David C, Savarirayan S, Sanes JR (1991) Integration site-dependent expression of a transgene reveals specialized features of cells associated with neuromuscular junctions. J Cell Biol 113: $1385-1397$.

Wu H, Fässler R, Schnieke A, Barker D, Lee KH, Chapman V, Francke U, Jaenisch R (1992) An X-linked human collagen transgene escapes $X$ inactivation in a subset of cells. Development 116:687-695.

Zimmerman K, Legouy E, Stewart V, DePinho R, Alt FW (1990) Differential regulation of the $\mathrm{N}-m y c$ gene in transfected cells and transgenic mice. Mol Cell Biol 10:2096-2103. 